\title{
An Investigation of Lung Mast Cell Behavior in a Rat Model of Migraine: Implications for Migraine Headache
}

\author{
Akciğer Mast Hücre Davranışının Migren Sıçan \\ Modelinde Incelenişi: Migren Baş Ağrısı Iç̧in \\ Çıkarımlar
}

\begin{abstract}
Aim: In this study, we aimed to investigate the potential role of lung mast cells in migraine by using a nitroglycerin-induced migraine model in rats

Materials and Methods: Thirty-five adult male Wistar rats were divided into five groups. Each treatment being performed intraperitoneally, the NS group received $0.2 \mathrm{ml}$ normal saline, the NTG group $10 \mathrm{mg} / \mathrm{kg}$ nitroglycerin, the NTG vehicle group $0.2 \mathrm{ml} 0.1 \%$ ethanol in normal saline, the L-NAME+NTG group 50 $\mathrm{mg} / \mathrm{kg} \mathrm{L}-\mathrm{NAME}+$ nitroglycerin, and the NS+NTG group normal saline + nitroglycerin. Two hours after the nitroglycerin and other treatments, the rats under anesthesia were intracardially perfused with a solution of $150 \mathrm{ml} 4 \%$ paraformaldehyde. The lungs were harvested and stained with toluidine blue to observe mast cells. The data were analyzed by using one-way ANOVA.

Results: Nitroglycerin increased significantly both number (from $94 \pm 3.8$ to $131 \pm 6.7, p=0.0035$ ) and percent of degranulation (from $11.8 \pm 1.3 \%$ to $35.5 \pm 5.7 \%, p=0.003$ ) of lung mast cells. However, L-NAME prevented the effects of nitroglycerin on the number and degranulation of lung mast cells, attenuating the increase in both number (from $136 \pm 5.1$ to $93 \pm 2.5, p=0.0011$ ) and degranulation percentage of lung mast cells (from $37.3 \pm 1.0 \%$ to $13.6 \pm 3.1 \%, p=0.001$ ) induced by nitroglycerin.

Discussion and Conclusion: Our findings demonstrate that nitroglycerin treatment leads to an increase in the number and degranulation of lung mast cells in a rat model of migraine induced by nitroglycerin Moreover, L-NAME prevented these effects, suggesting that nitric oxide released from nitroglycerin directly or indirectly leads to the activation of lung mast cells. The results obtained in the current study can pioneer new research on the role of lung mast cells in migraine.

Keywords: migraine; lung; mast cells; nitric oxide
\end{abstract}

Öz

Amaç: Bu çalışmada sıçanlarda nitrogliserin ile oluşturulan migren modeli kullanılarak akciğer mast hücrelerinin migrendeki muhtemel rolünü araştırmak amaçlanmıştır.

Gereç ve Yöntemler. Otuz beş yetişkin erkek Wistar sıçan beş gruba bölündü. Tüm uygulamalar intraperitoneal yoldan olmak üzere; NS grubuna 0,2 ml normal salin (serum fizyolojik), NTG grubuna 10 mg/kg nitrogliserin, vehikül NTG grubuna $0,2 \mathrm{ml}$ normal salin içinde $\% 0,7^{\prime}$ lik etanol, L-NAME+NTG grubuna 50 $\mathrm{mg} / \mathrm{kg} \mathrm{L-NAME}$ + nitrogliserin, NS+NTG grubuna ise $0,2 \mathrm{ml}$ normal salin + nitrogliserin uygulandı. Nitrogliserin ve diğer uygulamalardan iki saat sonra sıçanlar anestezi altında $150 \mathrm{ml} \% 4$ 'lük paraformaldehit ile intrakardiyak olarak perfüze edildi. Akciğerler alındı ve mast hücrelerini gözlemlemek için toluidin mavis ile boyandı. Veriler tek yönlü varyans analizi ile incelendi.

Bulgular. Nitrogliserin akciğer mast hücrelerinin hem sayısında ( $94 \pm 3,8$ 'den $131 \pm 6,7$ 'ye; $p=0,0035)$ hem

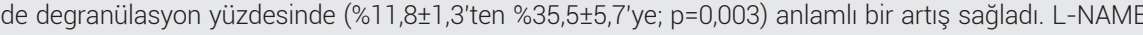
ise akciğer mast hücrelerinin sayı ve degranülasyonu üzerinde nitrogliserinin yol açtığı bu etkileri önledi, böylece akciğer mast hücrelerinin nitrogliserin ile tetiklenerek artan sayısını ve degranülasyon yüzdesini ayrı ayrı azalttı.

Tartışma ve Sonuç: Bulgularımız nitrogliserin ile oluşturulan migren sıçan modelinde nitrogliserin uygulamasının akciğer mast hücrelerinin sayısında ve degranülasyonunda bir artışa yol açtığını göstermiştir Ayrıca L-NAME'nin bu etkileri önlemiş olması, nitrogliserin kaynakıı nitrik oksidin direkt veya indirekt olarak akciğer mast hücrelerinin aktivasyonuna yol açtığını düşündürmektedir. Bu çalışmada elde edilen sonuçlar akciğer mast hücrelerinin migrendeki rolü üzerine yapılacak yeni araştırmalara öncülük edebilir. Anahtar Sözcükler. migren; akciğer; mast hücreleri; nitrik oksit
Erkan Kilinc ${ }^{1}$, Cemre Nur Balci ${ }^{2}$

Abant Izzet Baysal University, Faculty of Medicine, Department of Physiology, Bolu, Turkey

Abant Izzet Baysal University, Institute of Health Sciences, Department of Histology and Embryology, Bolu, Turkey

Geliş Tarihi /Received : 02.06.2018 Kabul Tarihi/Accepted: 06.07.2018

DOI: 10.21673/anadoluklin.429905

Sorumlu Yazar/Corresponding Author Erkan Kilinc

Abant Izzet Baysal University, Faculty of Medicine, Department of Physiology, 14280 Golkoy, Bolu, Turkey. E-mail: e_kilinc_27@hotmail.com 


\section{INTRODUCTION}

Mast cells (MCs) are multifunctional immune cells affecting a wide range of physiologic and pathophysiologic processes such as immunological responses, inflammation, migraine, arthritis, allergic reactions, and pulmonary hypertension (1). MCs are extensively distributed through the body and are located in most tissues such as the lungs, meninges, skin and gastrointestinal tracts. MCs contain a wide range of vasoactive, pro-inflammatory and pro-nociceptive mediators such as substance $\mathrm{P}(\mathrm{SP})$, calcitonin gene-related peptide (CGRP), pituitary adenylate cyclase-activating peptide (PACAP), serotonin, prostaglandins, bradykinin, histamine and many cytokines including tumor necrosis factor- $\alpha$ (TNF- $\alpha$ ) in their cytoplasmic granules $(2,3)$. MCs are able to trigger and promote inflammatory responses by releasing mixed mediators via the process of degranulation. There are various triggers such as stress, food, temperature changes, odors, SP, and CGRP that activate mast cells to release these mediators $(2,4)$. Migraine is a common neurovascular disorder characterized by recurrent unilateral head pain, nausea, photophobia, and phonophobia. Although numerous studies have so far been carried out to clarify the pathophysiology of migraine, the mechanisms underlying migraine pain have yet not been fully elucidated due to the disease's complex nature. However, it is well established that mast cells in the intracranial meninges are implicated in migraine pathophysiology (5-7). Degranulation of the mast cells in the meninges contribute to migraine pain by leading to neurogenic inflammation, and activation and sensitization of the trigeminovascular system (8). Experimental studies have shown that increased number and enhanced degranulation of mast cells in the meninges contribute to the generation and maintenance of migraine pain $(1,5,7)$. It has been demonstrated that mast cell mediators including serotonin, prostaglandin-I2, and histamine lead to the sensitization and activation of the meningeal nociceptors (9). In addition, dural mast cell degranulation causes prolonged activation of the trigeminal pain pathway underlying migraine pain (5). Moreover, we have recently shown that dural mast cell activation triggered nociceptive firing in the trigeminal nerve terminals innervating meninges (10).
Therefore, it is now well known that meningeal mast cells play a key role in migraine; but the role of lung mast cells in the pathophysiology of migraine remains unclear. Many studies reported a potent relationship between migraine headache, allergies, and asthma (11). It has been reported that migraine appears to be more prevalent in patients with allergy and asthma, which indicates the relationship of the mast cells (6). Previous studies reported that plasma histamine levels in migraine patients were found higher and that there was a further increase during migraine attacks $(12,13)$. In a clinical study including migraine patients with and without allergy, plasma histamine and total IgE levels were higher in migraine patients with allergy than in migraineurs without allergy (14). Therefore we hypothesized that there might be a potential link between migraine and lung mast cells. Accordingly, in the present study we aimed to investigate the potential role of lung mast cells in migraine by using a nitroglycerin-induced migraine model in rats.

\section{MATERIAL AND METHODS}

\section{Experimental animals}

Thirty-five Wistar male rats (150-200 g) were used in the experiments. They were given ad libitum a standard rodent diet and tap water, and were harbored in welfare lattices with a 12 -hour light/dark cycle at $22 \pm 2^{\circ} \mathrm{C}$. The experimental procedures were approved by the Animal Experiments Local Ethics Committee of the Abant Izzel Baysal University (license number 2016/28).

\section{Materials}

Nitroglycerin stock solution (5 $\mathrm{mg} / 0.5 \mathrm{ml}$ in $95 \%$ ethanol), L-nitroarginine methyl ester (L-NAME), toluidine blue, paraformaldehyde, and phosphatebuffered saline were purchased from Sigma-Aldrich (Schnelldorf, Germany).

\section{Experimental groups and procedures}

The thirty-five rats were divided into five groups. All injections being performed intraperitoneally, the normal saline (NS) group $(\mathrm{n}=7)$ received an injection of $0.2 \mathrm{ml}$ normal saline, the NTG group ( $\mathrm{n}=7) 10 \mathrm{mg} /$ $\mathrm{kg}$ nitroglycerin in normal saline, the NTG vehicle group ( $\mathrm{n}=7) 0.2 \mathrm{ml} 0.1 \%$ ethanol in normal saline, the L-NAME+NTG group (n=7) 50 mg/kg L-NAME (ni- 

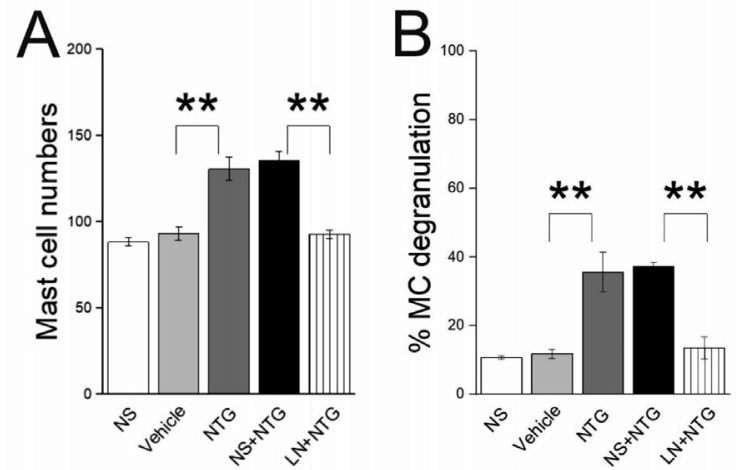

Figure 1. Effects of the nitroglycerin and L-NAME treatments on the number and degranulation state of lung mast cells.

(A) While nitroglycerin treatment alone increased the number of lung mast cells, L-NAME pretreatment attenuated the increases induced by nitroglycerin. (B) Similarly, while nitroglycerin treatment alone enhanced the degranulation of lung mast cells, L-NAME pretreatment prevented it.

${ }^{*} \mathrm{p}<0.01$; NS: normal saline; NTG: nitroglycerin; LN: L-NAME; MC: mast cell

tric oxide, NO, synthase inhibitor) $30 \mathrm{~min}$ prior to the nitroglycerin administration, and the NS+NTG group $(\mathrm{n}=7) 0.2 \mathrm{ml}$ normal saline $30 \mathrm{~min}$ prior to the nitroglycerin administration. Two hours after the nitroglycerin or other treatments, the rats were intracardially perfused with a solution of $100 \mathrm{ml}$ phosphate-buffered saline ( $\mathrm{pH} 7.4$ ), followed by $150 \mathrm{ml} 4 \%$ paraformaldehyde while they were under ketamine $(90 \mathrm{mg} / \mathrm{kg})$ anesthesia. Thereafter, the lungs were harvested and stored in $4 \%$ paraformaldehyde until stained with toluidine blue to observe the lung mast cells.

Lung tissue preparations and toluidine blue staining for mast cells

The left and right lungs were embedded in paraffin and cut into $5-\mu \mathrm{m}$-thick sections using a microtome. The sections were placed on the glass slides with polylysine; thereafter the sections were deparaffinized and then stained with toluidine blue $(\mathrm{pH} 2.5)$ for $10 \mathrm{~min}$ to observe the lung mast cells.

The lung mast cells were evaluated in terms of their granulation (intact), degranulation, and number, respectively, by use of a light microscope (Olympus CX21) by a blinded observer at $40 \mathrm{X}$ magnification in the bilateral five objective areas around the left and right main bronchi in each whole lung. The percent of degranulated lung mast cells for each rat was calculated as follows: [(number of degranulated mast cells) / (number of total mast cells)] x $100 \%$. Images of lung mast cells were taken by a camera (Nikon DS-Fil, Japan) attached to the microscope (Nikon Eclipse 80i, Japan).

\section{Statistical analysis}

The data were presented in mean \pm SEM (standard error of mean). Statistical analysis was carried out using SPSS for Windows (version 17.0, SPSS Inc., Chicago, IL, USA). The data obtained from the experimental groups were analyzed by one-way analysis of variance (ANOVA) followed by Tukey's multiple comparisons test. $\mathrm{p}<0.05$ was considered statistically significant.

\section{RESULTS}

In the present study, we used a nitroglycerin-induced rat model of migraine to mimic migraine headache in humans $(15,16)$. This model is considered a reliable method and is widely used by researchers worldwide. In order to establish this experimental model of migraine, we injected $10 \mathrm{mg} / \mathrm{kg}$ nitroglycerin to the rats. Nitroglycerin treatment increased significantly the number of lung mast cells, $(94 \pm 3.8$ in vehicle control versus $131 \pm 6.7$ in nitroglycerin, $p=0.0035$; Figure 1.A) and the percent of degranulated lung mast cells $(11.8 \pm 1.3 \%$ in vehicle control versus $35.5 \pm 5.7 \%$ in nitroglycerin, $\mathrm{p}=0.003$; Figure $1 . B)$. Lung mast cells in the vehicle control and nitroglycerin groups are shown in Figure 2.A and 2.B.

Nitroglycerin is a nitric oxide donor and regarded to exhibit its migraine-like effects via activation of nitric oxide synthase enzyme. We recently demonstrated that nitroglycerin treatment enhanced degranulation of mast cells in the meninges in a nitroglycerininduced rat model of migraine (7). Inducer effect of nitroglycerin on degranulation of mast cells in the meninges was also shown by another group previously (16). In the present study, however, we show for the first time that systemic administration of nitroglycerin also induces degranulation of lung mast cells in rats with nitroglycerin-induced migraine.

In addition, to verify the effects of nitroglycerin on the number and degranulation of lung mast cells, we administered a non-selective nitric oxide synthase inhibitor, L-NAME, 30 min prior to the nitroglycerin administration. L-NAME prevented the effects of nitroglycerin on both number (136 \pm 5.1 in the NS+NTG group versus $93 \pm 2.5$ in the L-NAME+NTG group, $\mathrm{p}=0.0011$; 
Figure 1.A) and degranulation percentage $(37.3 \pm 1 \%$ in NS+NTG versus $13.6 \pm 3.1 \%$ in L-NAME+NTG, $\mathrm{p}=0.001$; Figure 1.B) of lung mast cells. Images of lung mast cells in the NS+NTG and L-NAME+NTG groups are given in Figure 2.C and 2.D. Also, a populated image of lung mast cells in the NS group is shown in Figure 3.

\section{DISCUSSION AND CONCLUSION}

It is well known that mast cells in the meninges play a critical role in the pathophysiology of migraine $(5,6,10,17)$. Stress and chemical and mechanical stimuli induce the release of vasoactive and inflammatory neuropeptides such as SP and CGRP from the trigeminal nerve terminals in the meninges (18). SP and CGRP released from the trigeminal nerve terminals subsequently lead to the neurogenic inflammation underlying migraine pain by evoking degranulation of mast cells and vasodilation of blood vessels in the meninges (8). As a result of the degranulation of mast cells, mediators such as SP, NO, CGRP, VIP, prostaglandins, and histamine are released from the degranulated mast cells $(6,8)$. Consequently, these mediators further aggravate the neurogenic inflammation and migraine pain. For this reason, stabilization of mast cells and modulation of mast cell numbers are important targets in treatment of migraine pain.

Mast cells are located in close proximity to the afferent nerve terminals and blood vessels in the meninges and lungs, and this close proximity indicates a neuroimmune crosstalk. Similarly to the neurogenic inflammation in the meninges, afferent nerve terminals release sensory neuropeptides such as CGRP and the tachykinin substance P that induce mast cell degranulation in the lungs (19). As mentioned above, mediators released from the degranulated mast cells in the airways, too, cause vasodilatation, edema, plasma protein extravasation leading to pulmonary neurogenic inflammation. Although neurogenic inflammation in the airways was previously shown in experimental studies (20-22), involvement of lung mast cells in migraine headache remains unclear.

Previous epidemiologic studies suggested a relationship between migraine and respiratory disorders such as asthma (23-25). In a clinical study, it was reported that $31.9 \%$ of a total of 119 patients with chron-
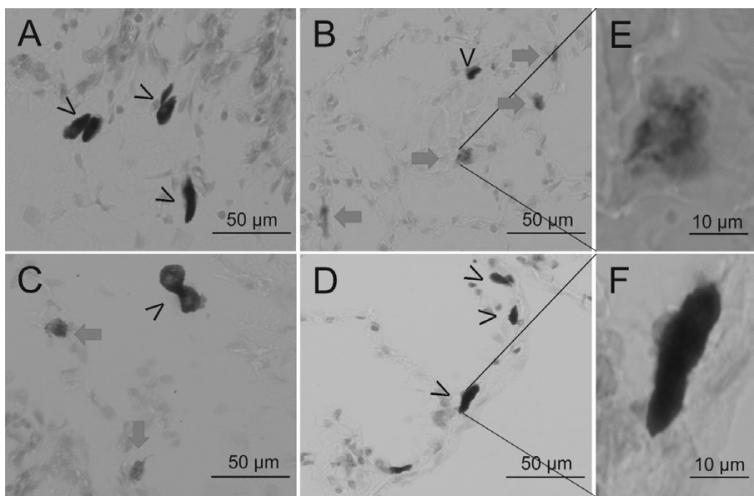

Figure 2. Intact and degranulated lung mast cells in the groups Microscopic images of the lung mast cells were taken at a magnification of $40 \mathrm{X}$ and 100X. (A) Intact lung mast cells in the vehicle control group, (B) degranulated lung mast cells induced by nitroglycerin, (C) degranulated lung mast cells in the NS+NTG group, (D) intact lung mast cells in the L-NAME+NTG group, (E) a degranulated lung mast cell in the NTG group at a magnification of 100X, (F) an intact lung mast cell in the L-NAME+NTG group at a magnification of $100 \mathrm{X}$. Open arrowheads show intact lung mast cells; solid arrows show degranulated lung mast cells in all groups. Note the enhanced degranulation of lung mast cells in both NTG and NS+NTG groups.

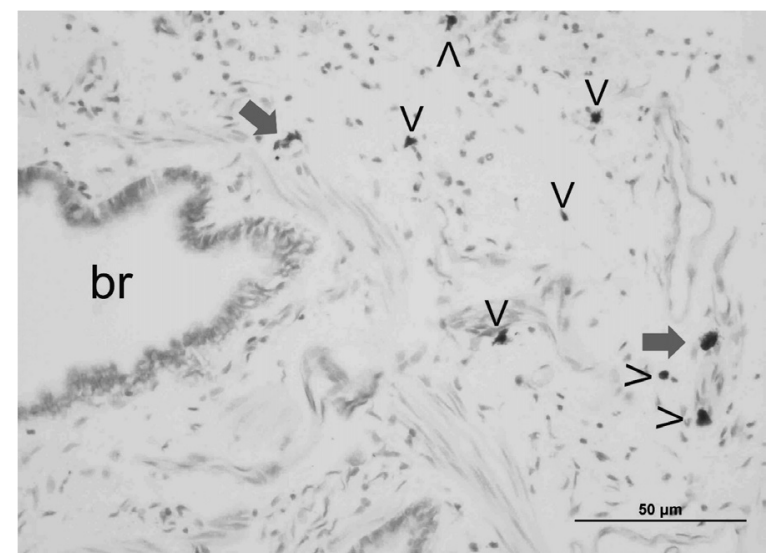

Figure 3. Overall image of lung mast cells

A populated image of lung mast cells in the NS group at a magnification of 20X. While open arrowheads show intact lung mast cells, solid arrows show degranulated lung mast cells.

br: bronchiole

ic obstructive pulmonary disease complained of headaches; moreover, $16 \%$ of the patients with headaches mainly had migraine (26). Moreover, a study investigating the risk of migraine in patients with asthma recently reported that the risk in the asthmatic group was 1.45-fold higher, compared to the non-asthmatic group (27). Similarly, two recent studies have also stated that patients with asthma have a high prevalence of migraine headaches $(28,29)$. 
As reported in the mentioned studies, it is well established that there is a link between migraine and respiratory disorders, particularly asthma. Nevertheless, there is currently no study that explains the mechanisms underlying the relationship between migraine and respiratory disorders. Therefore, in the present study, we show for the first time that lung mast cells are related to migraine pain. Consistently with several previous studies, we found increased numbers and enhanced degranulation of lung mast cells in rats with nitroglycerin-induced migraine. Previous studies reported that plasma histamine levels in migraine patients were increased (12-14). Taking into consideration that histamine hardly crosses the blood-brain barrier (30), it can be said that the plasma histamine source is mostly peripheral mast cells. Doubtlessly, the lung mast cells have a critical part in this. Histamine from the degranulated lung mast cells diffuses readily to the bloodstream because the lungs are constantly supplied with blood. Although this can explain why plasma histamine levels are higher in migraine patients with asthma, mast cell mediators other than histamine such as nitric oxide, serotonin, TNF- $\alpha$, PACAP, and VIP are also capable of inducing migraine pain (8). In particular, the role of NO in the pathophysiology of migraine is well established (6). In fact, the nitroglycerin-induced migraine model used in the present study is widely used by researchers, and this model is based on the release of nitric oxide. It is well known that nitric oxide is a strong vasodilator. It is considered that nitric oxide induces migraine pain by leading to vasodilation of meningeal and cerebral arteries and degranulation of mast cells in the meninges. This phenomenon is also compatible with the vasodilatory theory of migraine. Mast cells are capable of producing and releasing nitric oxide. In a study, prednisolone, an anti-inflammatory drug, reduced the intensity of the delayed head pain in migraineurs after nitroglycerin infusion (31). This report has further supported that dural mast cell degranulation is implicated in the pathophysiology of migraine.

Moreover, while it has been suggested that NO leads to mast cell degranulation through activation of sensory neurons (16), several previous reports reported contrarily that NO suppressed antigen-induced degranulation of mast cells (32-34). However, this ef- fect of NO is not an obstacle for it to induce mast cell degranulation through the other mechanisms.

Therefore, our results from a rat model of nitroglycerin-induced migraine suggest that nitroglycerin treatment leads to increased numbers and enhanced degranulation of lung mast cells. Moreover, L-NAME prevented these effects, suggesting that NO released from nitroglycerin may trigger an endogenous production of NO (16). The results obtained in this study can pioneer new research on the role of lung mast cells in migraine.

\section{Statement of Conflict of Interest}

The authors declare that there is no conflict of interest.

\section{REFERENCES}

1. Héron A, Dubayle D. A focus on mast cells and pain. J Neuroimmunol. 2013;264(1-2):1-7.

2. Theoharides TC, Alysandratos KD, Angelidou A, Delivanis DA, Sismanopoulos N, Zhang B, et al. Mast cells and inflammation. Biochim Biophys Acta. 2012;1822(1):21-33.

3. Kilinc E, Dagistan Y, Cetinkaya A, Tore F. The comparison of effects of applications of compound 48/80 and mast cell mediator suspension on inflammation in rats: a methodological study for acute inflammatory pain. Clin Exp Health Sci 2018. DOI: 10.5152/clinexphealthsci.2018.923.

4. Kilinc E, Dagistan Y, Kotan B, Cetinkaya A. Effects of Nigella sativa seeds and certain species of fungi extracts on number and activation of dural mast cells in rats. Physiol Int. 2017;104(1):15-24.

5. Levy D, Burstein R, Kainz V, Jakubowski M, Strassman AM. Mast cell degranulation activates a pain pathway underlying migraine headache. Pain. 2007;130(12):166-76.

6. Theoharides TC, Donelan J, Kandere-Grzybowska $\mathrm{K}$, Konstantinidou A. The role of mast cells in migraine pathophysiology. Brain Res Brain Res Rev. 2005;49(1):65-76.

7. Kilinc E, Dagistan Y, Kukner A, Yilmaz B, Agus S, Soyler G, Tore F. Salmon calcitonin ameliorates migraine pain through modulation of CGRP release and dural mast cell degranulation in rats. Clin Exp Pharmacol Physiol. 2018;45(6):536-46.

8. Ramachandran R. Neurogenic inflammation and its role in migraine. Semin Immunopathol. 2018. DOI: 10.1007/ 
s00281-018-0676-y.

9. Zhang XC, Strassman AM, Burstein R, Levy D. Sensitization and activation of intracranial meningeal nociceptors by mast cell mediators. J Pharmacol Exp Ther. 2007;322(2):806-12.

10. Kilinc E, Guerrero-Toro C, Zakharov A, Vitale C, Gubert-Olive M, Koroleva K, et al. Serotonergic mechanisms of trigeminal meningeal nociception: implications for migraine pain. Neuropharmacology. 2017;116:16073.

11. Kemper RH, Meijler WJ, Korf J, Ter Horst GJ. Migraine and function of the immune system: a meta-analysis of clinical literature published between 1966 and 1999 . Cephalalgia. 2001;21(5):549-57.

12. Heatley RV, Denburg JA, Bayer N, Bienenstock J. Increased plasma histamine levels in migraine patients. Clin Allergy. 1982;12(2):145-9.

13. Haimart M, Pradalier A, Launay JM, Dreux C, Dry J. Whole blood and plasma histamine in common migraine. Cephalalgia. 1987;7(1):39-42.

14. Gazerani P, Pourpak Z, Ahmadiani A, Hemmati A, Kazemnejad A. A correlation between migraine, histamine and immunoglobulin e. Scand J Immunol. 2003;57(3):286-90.

15. Ramachandran R, Bhatt DK, Ploug KB, Hay-Schmidt A, Jansen-Olesen I, Gupta S, et al. Nitric oxide synthase, calcitonin gene-related peptide and NK-1 receptor mechanisms are involved in GTN-induced neuronal activation. Cephalalgia. 2014;34(2):136-47.

16. Pedersen SH, Ramachandran R, Amrutkar DV, Petersen S, Olesen J, Jansen-Olesen I. Mechanisms of glyceryl trinitrate provoked mast cell degranulation. Cephalalgia. 2015;35(14):1287-97.

17. Jansen-Olesen I, Hougaard Pedersen S. PACAP and its receptors in cranial arteries and mast cells. J Headache Pain. 2018;19(1):16.

18. Malhotra R. Understanding migraine: Potential role of neurogenic inflammation. Ann Indian Acad Neuro. 2016;19(2):175-82.

19. Barnes PJ. Neurogenic inflammation in the airways. Respir Physiol. 2001;125(1-2):145-54.

20. Didier A, Kowalski ML, Jay J, Kaliner MA. Neurogenic inflammation, vascular permeability, and mast cells. Capsaicin desensitization fails to influence IgE-antiDNP induced vascular permeability in rat airways. Am Rev Respir Dis. 1990;141(2):398-406.

21. Muraki M, Iwanaga T, Haraguchi R, Kubo H, Tohda Y. Continued inhalation of lidocaine suppresses antigeninduced airway hyperreactivity and airway inflamma- tion in ovalbumin-sensitized guinea pigs. Int Immunopharmacol. 2008;8(5):725-31.

22. Qiu Z, Yu L, Xu S, Liu B, Zhao T, Lü H, et al. Cough reflex sensitivity and airway inflammation in patients with chronic cough due to non-acid gastro-oesophageal reflux. Respirology. 2011;16(4):645-52.

23. Davey G, Sedgwick P, Maier W, Visick G, Strachan DP, Anderson HR. Association between migraine and asthma: matched case-control study. Br J Gen Pract. 2002;52(482):723-7.

24. Aamodt AH, Stovner LJ, Langhammer A, Hagen K, Zwart JA. Is headache related to asthma, hay fever, and chronic bronchitis? The Head-HUNT Study. Headache. 2007;47(2):204-12.

25. Kaleagasi H, Özgür E, Özge C, Özge A. Bronchial hyperreactivity in migraine without aura: is it a new clue for inflammation? Headache. 2011;51(3):426-31.

26. Ozge A, Ozge C, Oztürk C, Kaleagasi H, Ozcan M, Yalçinkaya DE, et al. The relationship between migraine and atopic disorders-the contribution of pulmonary function tests and immunological screening. Cephalalgia. 2006;26(2):172-9.

27. Peng YH, Chen KF, Kao CH, Chen HJ, Hsia TC, Chen $\mathrm{CH}$, et al. Risk of migraine in patients with asthma: a nationwide cohort study. Medicine (Baltimore). 2016;95(9):e2911.

28. Turan MO, Susuz ÇÇ, Turan PA. Presence of headache and migraine in asthma patients. Turk Thorac J. 2017;18:47-51.

29. Dirican N, Demirci S, Cakir M. The relationship between migraine headache and asthma features. Acta Neurol Belg. 2017;117(2):531-6.

30. Haas HL, Sergeeva OA, Selbach O. Histamine in the nervous system. Physiol Rev. 2008;88(3):1183-241.

31. Tfelt-Hansen P, Daugaard D, Lassen LH, Iversen HK, Olesen J. Prednisolone reduces nitric oxide-induced migraine. Eur J Neurol. 2009;16(10):1106-11.

32. Coleman JW. Nitric oxide: a regulator of mast cell activation and mast cell-mediated inflammation. J Clin Exp Immunol. 2002;129(1):4-10.

33. Sekar Y, Moon TC, Muñoz S, Befus AD. Role of nitric oxide in mast cells: controversies, current knowledge, and future applications. Immunol Res. 2005;33(3):22339.

34. Eastmond NC, Banks EM, Coleman JW. Nitric oxide inhibits IgE-mediated degranulation of mast cells and is the principal intermediate in IFN-gamma-induced suppression of exocytosis. J Immunol. 1997;159(3):1444-50. 